\title{
Peran Director of Photograpy Dalam Menginterpretasikan Visual Pada Web Series di Youtube
}

\author{
Niken Ilyas ${ }^{1}$, Shulhuly Ashfahani ${ }^{2}$ \\ ${ }^{1,2}$ Sekolah Tinggi Ilmu Komunikasi Indonesia Maju \\ Email correspondent: nikenilyas28081994@gmail.com
}

\begin{abstract}
Abstrak
Ngabuburit series merupakan film yang ditayangkan di youtube. Dimana pada proses pembuatannya terdapat seorang Director of photography yang membuat film ini menarik.selain merekam gambar, Director of photograpy juga mengsukseskan visi sutradara melalui visual yang diinginkan, oleh karena itu Director of photograpy harus menginterpretasikan citra visual dan menilai penting atau tidak nya objek tersebut. Tujuan penelitian ini untuk mengetahui peran Director of photograpy menginterpretasikan visual dalam film di youtube ngabuburit series. Metode yang digunakan dalam penelitian ini adalah kualitaitf dengan jenis penelitian. Studi kasus jenis dan tehnik pengumpulan data adalah data primer yang diperoleh dari wawancara, sementara data sekunder diperoleh dari data yang berbentuk buku, web, dan artikel. Hasil penelitian yang diperoleh, Director of Photography memiliki peran penting dalam menjaga keberlangsungan proses produksi Ngabuburit Series. Peran Director Of Photography adalah memperhatikan tata kamera dan menginterprestasikan tulisan menjadi visual yang dibutuhkan difilm Ngabuburit Series. Peran Director of photograpy sangat penting untuk kesuksesan sebuah film yang diperlihatkan secara visual.
\end{abstract}

Kata Kunci: peran director of photography, job desk director of photography, web series

\begin{abstract}
Ngabuburit Series is a film that aired on youtube. Where in the manufacturing process, the Director of photography makes the film interesting besides recording images. Director of photography also succeded in the vision of Director through the desired visuals. Therefore, the Director of photography must interpret the visual representation and asses the importance or not of object. This study used qualitative methods with a type of case study research. Type and techniques of data collection are primary data obtained from the interview, while secondary data obtained from data in the form of book, web and articles. The results of the research obtained indicate that the Director of photography has an important role in the production process of the ngabuburit series. The role of Director of photography takes into account the camera layout and interprets the writing into the visual needed in the Ngabuburit Series film. For success of film that is shown visually the role of Director of photography is very important
\end{abstract}

Keywords: role director of photography, jobdesk director of photography, web series 


\section{Pendahuluan}

Definisi komunikasi massa yaitu proses komunikasi yang berlangsung dimana pesannya dikirim dari sumber yang melembagakan kepada khalayak yang bersifat masal, seperti radio, televisi, surat kabar, dan film. ${ }^{16}$ Dari definisi tersebut dapat kita ketahui bahwa komunikasi massa itu harus menggunakan media massa. Jadi sekalipun komunikasi itu disampaikan kepada khalayak yang banyak, seperti rapat akbar dilapangan luas yang dihadiri oleh ribuan orang, bahkan ratusan ribu orang, jika tidak menggunakan media massa, maka itu bukan komunikasi massa. Media komunikasi yang termasuk media adalah, radio, dan televisi, keduanya dikenal sebagai media elektronik, surat kabar dan majalah dikenal sebagai media cetak serta media film. Film sebagai media komunikasi massa adalah bioskop. ${ }^{1}$

Perkembangan media sosial yang semakin pesat tidak hanya terjadi pada negara-negara maju saja, tetapi di negara berkembang seperti tanah air kita ini, Indonesia banyak sekali user atau pengguna sosial media dan perkembangan yang pesat ini bisa menjadi pengganti peran media massa 18 atau konvensional dalam menyebarkan berita atau informasi. Media online dan media sosial hadir memudahkan penggunaannya dalam melakukan komunikasi tanpa batas ruang dan waktu termasuk didalamnya adalah Youtobe hadir sebagai media sosial yang terpopuler di masyarakat. Youtobe merupakan salah satu jejaring sosial yang dapat mengekspresikan diri yang berbeda dengan jejaring sosial lainnya.

Web series adalah salah satu bentuk tontonan internet. Istilah web series juga dikenal sebagai web episode. Konsep web series ini mirip dengan program acara televisi namun dengan durasi tayang yang relatif pendek, sekitar 5-15 menit. Format acaranya bisa bermacam-macam, seperti sinetron atau FTV (film televisi), talkshow. tips dan trik, tutorial, berita maumpun serial video blog/vlog. Suatu web series biasnya terbagi dalam episode-episode dimana waktu penayangannya atau lebih tepatnya upload, biasnya mengikuti pola yang ada ditelevisi. Episode baru akan muncul sekali seminggu, tiap hari senin. Namun patokan itu tidak selalu baku, bisa saja berubah tergantung dari situasi kondisi yang terjadi di lapangan, misalnya ada kendala.

Penonton dapat mengakses web series melalu internet dengan menggunakan computer, baik desktop maupun laptop, dna juga telepon seluler. Web series ini merupakan suatu produk atau bagian dari televise web, suatu bentuk media teknologi informasi baru. Umumnya orang menggunakan atau menampilkan web series disitus penyedia layanan video streaming, seperti youtube atau Vimeo. Keuntungan yang diberikan situs semacam ini diberikan adalah diberikannya akun khusus yang dinamakan channel, seperti halnya sebuah channel televisi eklusif. ${ }^{2}$ Dari penjelasan diatas, peneliti bisa simpulkan bahwa film webseries ngabuburit series ini terbagi menjadi beberapa episode yang tayang di youtube, tujuan nya untuk menghibur penonton dan menyambut momentum bulan rahmadan.

Dalam produksi film pada umumnya yang dibuat adalah pendekatan keseharian dan perilaku masyarakat yang ada didalam film atau lebih dikenal dengan istilah realisme. Unsur naratif sendiri berhubungan dengan tema, sedangkan unsur sinematik jalan ceritanya. Sedangkan dalam film secara umum dapat dibagi mejadi dua unsur yaitu pembentukan unsur naratif dan sinematik. Bisa dikatakan bahwa unsur naratif adalah bahan (materi) yang akan diolah, sementara unsur sinematik adalah cara (gaya) untuk mengolahnya. Unsur sinematik terbagi menjadi empat elemen pokok yakini, mise en scene, cinematograpy, editing, dan suara. ${ }^{3}$ Dapat dijelaskan bahwa film bagian dari media komunikasi massa memang tidak lepas dari hubungan antara film dan masyarakat itu sendiri, seperti yang dikemukakan oleh Oey Hong Lee yakni, "film sebagai alat komunikasi massa kedua yang muncul di dunia, mempunyai masa pertumbuhannya pada akhir abad ke-19 dengan perkataan lain pada waktu yang merintangi perkembangan surat kabar yang sudah jarang sekali. Ini berarti bahwa dari permulaan sejarahnya filmdengan lebih mudah dapat menjadi alat komunikasi yang sejati, karena ia tidak mengalami seperti teknik, politik, ekonomi, sosial dan demografi yang merintangi kemajuan surat kabar pada masa pertumbuhannya. ${ }^{4}$

Menurut kutipan website dunia sinematograpy http://.blogspot.co.id menjelaskan, sinematograpy adalah kata serapan dari bahasa inggris cinematograpy yang berasal dari bahasa yunani "kinema" yang berarti gerakan dan "graphoo" yang berarti menulis. Sinematografi adalah kegiatan 
menulis yang menggunakan gambar bergerak, seperti apakah gambar-gambar itu, bagaimana merangkai potongan-potongan gambar yang bergerak menjadi rangkaian gambar yang mampu menyampaikan maksud tertentu atau informasi atau menyampaikan ide tertentu. Sinematografi sebagai ilmu terapan merupakan bidang ilmu yang membahas tentang teknik menangkap gambar dan menggabungkan gambar tersebut sehingga menjadi rangkaian penyampai ide (dapat mengemban cerita). Sinematografi juga diartikan segala perbincangan mengenai sinema (perfilman) baik dari estetika, bentuk, fungsi, makna, produksi, proses, maupun penontonnya jadi seluk beluk perfilman dikupas tuntas dalam sinematografi. ${ }^{5}$

Dalam pembuatan film, seorang Director of Photograpy tidak hanya merekam objek, gambar yang dihasilkan nantinya, diharapkan dapat dinikmati dan bisa ikut mempengaruhi suasana (mood) penontonnya, misalnya dalam film horror seorang Director of Photograpy akan membuat suasana pada gambar akan lebih gelap dibandingkan film dengan genre drama, dengan harapan penonton akan terbawa situasi yang menakutkan dan mencekam. Director of photograpy adalah seorang yang bertanggung jawab pada semua dalam pembuatan sebuah film Ngabuburit Series termasuk dalam interpretasi visual dalam pembuatan film ini dan Mancakup penafsiran visual pada skenario supaya pesan yang dirsampaikan dapat dirasakan penonton lewat pengambilan gambar.

Adapun kewajiban Director of photograpy sebagai menganalisa skenario dan sekaligus membahasnya bersama sutradara agar dapat mencapai tujuan bersama dalam penafsiran serta mewujudkan gagasan penulis dalam bentuk nyata dengan menciptakan konsep yang telah disepakati bersama untuk mencapai isi dalam ceritan tersebut. Seorang Director of photograpy harus menafsirkan (interpretasi) visual dan mengenali objek pada visual dengan cara menganalisis, kemudian menilai penting atau tidaknya objek tersebut. Pengenalan objek visual berdasarkan karakteristik tertentu yang disebut unsur interpretasi visual. Ada delapan interpretasi visual diantaranya, rona/warna, tekstur, bentuk, ukuran, pola, situs, bayangan, dan asosiasi. ${ }^{6}$

Suatu karya film tidak hanya ditonton di televisi, akan tetapi berkat kemajuan teknologi, sebuah karya film dapat di tonton melalui media internet seperti youtube. Media sosial adalah Media sosial online yang mendukung interaksi sosial. Media sosial menggunakan teknologi berbasis web yang mengubah komunikasi menjadi dialog interaktif ". Melalui media sosial, setiap orang bisa membuat, menyunting sekaligus mempublikasikan sendiri konten berita, promosi, artikel, foto dan video, perkembangan media sosial yang semakin pesat tidak hanya terjadi pada negara-negara maju saja, tetapi di negara berkembang seperti tanah air kita ini, Indonesia banyak sekali user atau pengguna sosial media dan perkembangan yang pesat ini bisa menjadi pengganti peran media massa atau konvensional dalam menyebarkan berita atau informasi. ${ }^{17}$

Terkait struktur film menyatakan bahwa stuktur film ada 3, yaitu shot, scene, dan sequence: Shot adalah bagian dari adegan. Cara membuat 1 shot film yaitu merekam gambar mulai kemara diaktifkan (on) hingga kamera diberhentikan (off), itulah yang disebut dengan 1 shot. 1 shot berdurasi kurang dari 1 detik, beberapa menit, bahkan jam. Agar sambungan gambar-gambar tersebut dapat menceritakan sesuatu dan mudah dipahami oleh penonton dengan mudah, maka harus ada unsur-unsur yang menunjukannya, unsur-unsur tersebut dapat dicari dalam komposisi gambar-gambar itu sendiri. Misalnya obyek yang bergerak dalam frame dalam dialog yang diteruskan atau dalam hubungan penonton denagn obyek-obyek dalam cerita itu sebagai akibat dari letak kamera atau lensa khusu yang dipergunakan.

Scene (adegan), alinea dalam bahasa televisi Scene adalah gabungan dari shot-shot, scene berarti satu segmen pendek dari keseluruhan cerita yang memperlihatkan satu aksi kesinambungan yang diikat oleh ruang. Waktu, isi (cerita), tema, karakter, atau motiv. Untuk membuat scene, shot-shot dihubungkan satu dengan yang lain. Hal penting yang diperlukan dalam sebuah scene adalah sebuah adegan atau action yang dipandang dari beberapa sudut kamera. Misalnya, sebuah scene mengenai perkelahian, maka gambar yang tampak adalah adegan perkelahian dari sudut kiri dan kanan, dari lawan satu ke lawan yang lain. Sequence adalah gabungan dari scene- scene, sequence berarti satu segmen besar yang memperlihatkan satu rangkaian peristiwa yang utuh dan diperoleh suatu mood tertentu. 1 
sequence terdiri dari beberapa adegan yang saling berhubungan. 1 sequence dikelompokan berdasarkan satu periode, lokasi, atau serangkaian aksi panjang. Peneliti menyimpulkan bahwa struktur film sangat penting untuk film ngabuburit series, karna didalam film terdapar elemen-elemen penting seperti shot,scene, dan sequence yang memperkuat film itu sendiri. ${ }^{7}$

Media online dan media sosial hadir memudahkan penggunaannya dalam melakukan komunikasi tanpa batas ruang dan waktu termasuk di dalamnya adalah Youtobe hadir sebagai media sosial yang terpopuler di masyarakat. Youtobe merupakan salah satu jejaring sosial yang dapat mengekspresikan diri yang berbeda dengan jejaring sosial lainnya Youtube merupakan video sharing yang berfungsi sebagai sarana untuk berbagi video secara online. Situs ini memudahkan penggunanya untuk upload video yang di akses oleh pengguna-pengguna yang mempunyai akun youtobe diseluruh dunia secara gratis. Oleh karena itu Youtube yang menampilkan audio dan visual juga selalu memberikan pesan dari setiap postingan video penggunanya.

Salah satu bentuk konten youtube yang ditawarkan para kreator adalah web series. Web series adalah film drama yang tayang pada plafrom video non drama televisi (Youtube). Web series sendiri biasanya memiliki durasi tak sepanjang film yang ditayangkan dibioskop, namum secara kualitasnya web series sudah layak disandingkan dengan film layar lebar. Kebutuhan generasi saat ini lebih menekan pada keragaman yang bisa dinikmati dalam waktu singkat, isi konten bervariasi dan cara mengaksesnya yang cukup mudah dengan harga terjangkau juga menjadi kelebihan web series jika dibandingkan dengan program televisi atapun film layar lebar. Web series mampu mengakomodi kebutuhan penonton yang berbeda dari biasanya. Jika penonton lebih sering menikmati film lewat bioskop, kini berbagai film bahkan tayangan dengan format lainnya bisa dinikmati melalui telepon seluler. ${ }^{8}$

Director Of Photograpy bertanggung jawab untuk memberikan apa yang sutradara inginkan, juga menyelesaikan gaya fotografi yang sudah disetujui. Setiap sutradara memiliki cara berkerja yang berbeda-beda, ada yang sangat detil tentang "look"yang ia inginkan dan tentu saja framing, sedangkan ada yang fokus terhadap actor dan pengadeganan dan menyerahkan kepada Director of photofrapy untuk memutuskan framing, pergerakan kamera, pencahayaan dan sebagainya. Sutradara sebagai pemimpin produksi mampu bekerja. Disegala model yang diharapkan. Director Of Photograpy yang professional memiliki fleksibelitas untuk bekerja bersama sutradara bagaimanapun sikapnya. Ini penting untuk didiskusikan sebelum proses shooting dimulai, dan jika Director of Photograpy tidak nyaman dengan cara sutradara bekerja, maka bisa ditanggulangi secepatnya. Peran Director Of Photograpy sangat besar untuk menyampaikan tampilan visual yang sutradra inginkan dan memastikan footage sesuai dengan keinginan sutradara dan editor. Tanggung jawab Director of Photograpy. ${ }^{9}$

Bentuk film merupakan sesuatu yang berpola dan bersifat tetap, sedangkan isi adalah sesuatu bisa berubah dan selalu mengikuti bentuknya. Bila dilibatkan bentuk adalah ember, gelas, ataupun botol, maka isinya bisa bermacam-macam baik air, minyak, pasir, gula, dan sebagainya. Misalnya air akan mengikuti bentuk embernya, gelas atau botolnya. Begitu pula denagan cerita, kita bisa menggunakan cerita yang sama persis secara isi namun bisa dikemas dengan bentuk yang berbeda maka cerita tersebut akan memiliki kesan yang berbeda pula. Bayangkan bila kita punya cerita percintaan antara Kiara dan Dondi, biasanya urutan waktu yang digunakan adalah linier dan progresif (maju kedepan). Tetapi bayangankan kalau ceritanya dimulai dari mereka menjadi sepasang kekasih sampai berakhir saat awal mereka berkenalan, artinya urutan waktunya berjalan mundur. Secara isi bisa jadi sama persis, namun secara bentuk waktunya berjalan mundur maka kesan yang ditangkap penotnon akan berbeda.

Bagaimanapun, bentuk film harus bisa dirasakan oleh penontonnya, sehingga berbicara tentang rasa maka hal itu terdiri dari dua aspek, yaitu rasa yang dialami tokoh dan rasa yang diterima oleh penonton. Sesuatu yang dirasakan tokoh tentu saja seperti sedih, senang, jatuh cintah dan sebgainya. Rasa ini secara umum harus bisa dirasakan juga oleh penontonnya, namun apa yang dirasakan penonton tidak selalu harus dirasakan oleh tokoh dalam filmnya. ${ }^{10}$ Misalnya penonton bisa merasa cemas ketika tokoh hendak dipukul dari belakang, padahal pada adegan itu sang tokoh sedang melakukan rutinitasnya 
(sedang tidak mengalami rasa apapun) atau contoh lain misalnya tokoh yang sedang dikejar hantu, menemukan tempat bersembunyian yang dianggap aman, namun ternyata tampat itu justru sarang hantu tersebut. ${ }^{11}$

Web series pertama kali diproduksi oleh Bulleseye Art pada tahun 1995 dengan material serial animasi pendek. Beberapa judul yang sempat popular adalah "Miss Muffy and the Muf Mob"dan "Space Dog”. Pada tahun 2003 microsoft meluncurkan MSN video TV 2000'. Dari 2003 hingga 2006, beberapa seri wev independen mulai mencapai popularitas, terutama 'Red Vs Blue'produksi Rooster Teeth. Film web series Ngabuburit Series film ini sarat dengan makna seperti membuat pesan- pesan moral baik yang dapat dilihat dari segi aspek sastra, dramatis dan bahasa maupun sinematiknya. Film ini diperankan oleh kevin Hendrawan sebagai Kevin, Faris Nahdi sebagai Ario dan Nina Samsolese sebagai Tia. Film yang disutradari oleh Oktiarini Imaniar ini terbilang sukses dengan 289.234 viewers di youtube, karena dalam film ini menceritakan tentang toleransi umat beragama dalam menjalin rasa persaudaraan dari setiap perbedaan. ${ }^{12}$

Didalam sebuah produksi web series seperti film Ngabuburit Series, terdapat posisi-posisi penting seperti produser yang mengawasi dan menyalurkan sebuah proyek film kepada seluruh pihak yang dilibatkan dan mempertahankan kekompakan antar divisi, sedangkan sutradara bertanggung jawab atas aspek-aspek kreatif pembuatan film, baik pengambilan gambar (Interprestasi visual) maupun teknis, sutradara menduduki posisi tertinggi dari segi artistik dan memimpin pembuatan film, penulis skenario biasanya yang menulis atau membuat kerangka cerita film. ${ }^{13}$

Dari paparan di atas peneliti ini memfokuskan untuk meneliti kenapa Peran Director of photograpy sangat penting salah satunya melalui pengambilan gambar (Interprestasi visual) yang diambil dengan beberapa adegan yang membuat menarik penonton seperti adegan-adegan yang membuat penasaran terhadap film web series tersebut Dan untuk menaikan para penonton pada produksi film ini khususnya memilih youtobe yang sangat digemari dikalangan masyarakat saat ini dan merupakan media sosial yang dapat menaikan citra oleh penonton. ${ }^{14}$

Tujuan dari penelitian ini adalah untuk mengetahui Peran Director of Photograpy Dalam Menginterretasikan Visual Pada Web Series Di Youtube"15

\section{Metode}

Penelitian ini merupakan penelitian deskriptif dengan pendekatan kualitatif. Penelitian deskriptif yaitu penelitian yang bertujuan membuat deskripsi secara sistematis, faktual, dan akurat tentang faktafakta serta sifat tertentu. Pendekatan kualitatif yang dimaksud sebagai prosedur penelitian yang menghasilkan data deskriptif berupa kata-kata tertulis atau lisan dari orang-orang dan perilaku yang dapat diamati. Penelitian deskriptif yang tepat cukup dari semua aktivitas, objek, proses, dan manusia. Penelitian deskriptif berkaitan dengan pengumpulan fakta dan data secara valid untuk memberikan gambaran mengenai objek yang diteliti. Dengan metode kualitatif ini, diharapan tidak ada jarak antara peneliti dan surber informasi, sehingga dalam meneliti dapat menjawab fenomena yang peneliti temukan pada informan serta lebih memihami objek yang diteliti.

Dengan menggunakan metode ini diharapkan peneliti dapat mengetahui dan mengkaji Peran Director of Photografy Dalam Menginterpretasikan Visual Pada Web Series Di Youtobe (Studi Deskriptif Kualitatif Web Series Ngabuburit 2018). Adapun yang menjadi sumber informasi (key informan) dan informan atau narasumber untuk mendapatkan berbagai informasi yang dibutuhkan dalam penelitian pada wawancara mendalam yang berlangsung diajukan pertanyaan-pertanyaan secara detail untuk mendapatkan data yang diinginkan, akurat dan sesuai dengan format penelitian. Peneliti melakukan penelitiannya di PT Origami Picture. Penelitian ini memerlukan waktu kurang lebih satu bulan, Periode april 2018 - juni 2018 dalam penelitiannya. Peneliti mengamati proses peran director of photograpy menginterpretasikan visual sinematografi Film web series ngabuburit saat produksi berlangsung, peneliti menganalisis bagaimana peran DOP dalam memvisualkan film web sries tersebut.

Dalam penelitian ini, pengumpulan data diperoleh dari data primer dan data sekunder. Data primer diperoleh melalui wawancara dengan beberapa key informan, yaitu produser, sutradara, director of 
photography, Director. Wawancaran merupakan suatu percakapan, seni tanya jawab dan mendengarkan. Ini bukan merupakan suatu alat yang netral, pewawancara menciptakan situasi tanya jawab yang nyata. Dalam situasi ini jawaban-jawaban diberikan. Wawancara menghasilkan pemahaman yang terbentuk oleh situasi berdasarkan peristiwa- peristiwa interaksional yang khusus. Metode tersebut dipengaruhi oleh karakteristik individu pewawancara, termasuk ras, kelas, kesukuan, dan gender. Proses wawancara yang dilakukan oleh informan menggunakan guideline yaitu beberapa pertanyaan yang sifatnya terbuka yang memungkinkan peneliti mengeksplore pertanyaan yang muncul pada saat wawancara. Selama proses wawancara agar informasi data- data dari informan tersimpan peneliti meng- gunakan perekam suara. Wawancara tidak berstuktur dengan uatu tujuan yang biasanya mengutamakan perekaman dan transkip data verbatim (kata perkata). ${ }^{7}$

Selain wawancara, data primer juga didapatkan dari proses observasi. Pengamatan dilakukan terhadap proses produksi sinematografi film ngabuburit serta bagaimana cara mempromosikan film dalam bentuk teaser tersebut dapat meningkatkan jumlah viewers. Observasi merupakan suatu teknik pengumpulan data yang dilakukan dengan cara mengadakan penelitian secara teliti, serta pencatatan secara sistematis. Observasi dilakukan untuk mendekatkan peneliti ke orang- orang yang ditelitinya dan ke situasi atau lingkungan mereka yang sebenarnya. Wawancara adalah hasil bersama seorang peneliti dan satu atau lebih anggota. Anggota adalah peserta aktif yang wawasan, perasaan, dan kerjasamanya menjadi bagian penting dari proses pembahasan yang mengungkapkan makna subjektif. Dokumentasi adalah metode pengumpulan data yang datanya diperoleh dari buku, internet, atau dokumen lain yang menunjang penelitian yang dilakukan.

Reduksi Mereduksi berarti merangkum, memilih hal-hal pokok dan penting kemudian dicari tema dan polanya, setelah direduksi data akan mengerucut, semakin sedikit dan mengarah ke inti permasalahan sehingga mampu memberikan gambaran yang lebih jelas mengenai objek penelitian. Pengambilan Kesimpulan tahap akhir pengolahan data adalah data tersaji permasalahan yang menjadi objek penelitian dapat dipahami dan kemudian ditarik kesimpulan yang merupakan hasil dari penelitian ini.

\section{Hasil dan Pembahasan \\ Peran Director of photograpy dalam Ngabuburit Series}

Film merupakan media audio-visual yang memaparkan pesan yang ditangkap melalui indra penglihatan serta indra pendengaran. Dalam proses komunikasi film merupakan salah satu alat penyampaian berbagai jenis pesan. Film juga sering disebut sebagai video atau movie. Film dalam penelitian ini adalah sebuah karya dari Oktariani Immaniar yang berjudul "Ngabuburit Series". Ngabuburit Series adalah film Indonesia ber-genre drama komedi, dimana dalam film ini lebih banyak menceritakan pertemanan dan percintaan. Film ini ditulis oleh penulis skenario Stephanie Paskalita. Film yang dibintangi oleh Kevin Hendrawan, Faris Nahdi dan Nina Samsolese serta ada beberapa pemeran pembantu lainnya. Soundtrack film ini dibuat oleh Althof Mirasa.

Dalam pengelolaan film Ngabuburit series, peran seorang Director of Photogrphy adalah membuat konsep sesuai arahan yang sutradara inginkan, Director of photograpy ingin menafsirkan visual yang mempersempit ruangan dengan membuat frame di dalam frame untuk menjadikan adegan tersebut terlihat lebih intim seperti yang diutarakan oleh sutradara Oktania Imania:

Peran Director of photograpy tentunya sangat besar dalam pembuatan karya ngabuburit series ini, untuk mewujudkan hasil yang baik, tentunya perlu dilakukan kerjasama yang baik antara sutradara dan Director of photograpy sutradara mempunyai konsep yang diinginkan dan Director of photograpy mewujudkan visualiasi yang diingikan sutradara. Director of photograpy tentunya sangat berperan penting dalam menentukan konsep visual, warna asli, lighting, dan framing.

Dalam tugas Director of Photography dilakukan dari tahapan awal sampai tahapan akhir sangatlah penting yaitu, seperti yang diutarakan oleh Guntur Arif Saputra selaku Director of Photography. Tugas dari Director of photograpy itu menjalankan konsep cerita dari sutradara untuk dijadikan visual yang dapat menyampaikan pesan untuk penontonnya. Sebelum proses produksi 
dimulai, saya sutradara dan team melakukan recce (cek lokasi) untuk menentukan shot yang diingikan sutradara, setelah itu kita lakukan ppm (pra produksi meeting) untuk bedah naskah bersama-sama

Dari wawancara diatas Ppeneliti dapat menyimpulkan bahwa peran dan tugas dari seorang Director of Photography sangatlah penting saat proses pra produksi sampai produksi sebuah film seperti mendiskusikan shot ketika recce (cek lokasi) dan menentukan konsep visual, warna asli, lighting, dan framing pada film ngabuburit.

Ngabuburit series peran Director of photograpy sangat penting untuk mengkonsultasikan tentang shot. Selain tugas dan peran yang penting, Director of photograpy juga mempunyai fungsi dalam proses produksi sebuah film. Fungsi dari Director of Photography menurut wawancara dengan Guntur Arief Saputra selaku Director of Photography dalam film Ngabuburit series:

Fungsi Director of photograpy disini mendiskusikan konsep visual yang diingikan sutradara dan menginterpretasikan konsep tertulis dari penulis menjadi sebuah visual yang diharapkan sutradara, dan difilm ngabuburit series ini sutradara menginginkan visual yang realis dari set sampai pencahayaannya, hal ini membuat saya sebagai Director of photograpy harus memikirkan tata cahaya yang sesuai agar look dari film sesuai yang diingikan sutradara.

Masih mengenai fungsi dari Director of Photograp yang diungkapkan oleh sutradara Oktania Imaniar seperti yang diuraikan dibawah ini; tentunya perlu dilakukan kerjasama yang baik antara sutradara dan Director of photograpy sutradara mempunyai konsep yang diinginkan dan Director of photograpy mewujudkan visualiasi yang diingikan sutradara. Director of photograpy tentunya sangat berperan penting dalam menentukan konsep visual, warna asli, lighting, dan framing. Dapat ditarik kesimpulan bahwa fungsi dari seorang Director of Photography adalah mendiskusikan konsep visual dan menginterpretasikan konsep menjadi sebuah visual yang diharapkan sutradaranya, serta menginginkan visual yang realis dari set sampai pencahayaannya sampai pergerakan kamera, selain itu director of photograpy tentunya sangat berperan penting dalam menentukan konsep visual, warna asli, lighting, dan framing.

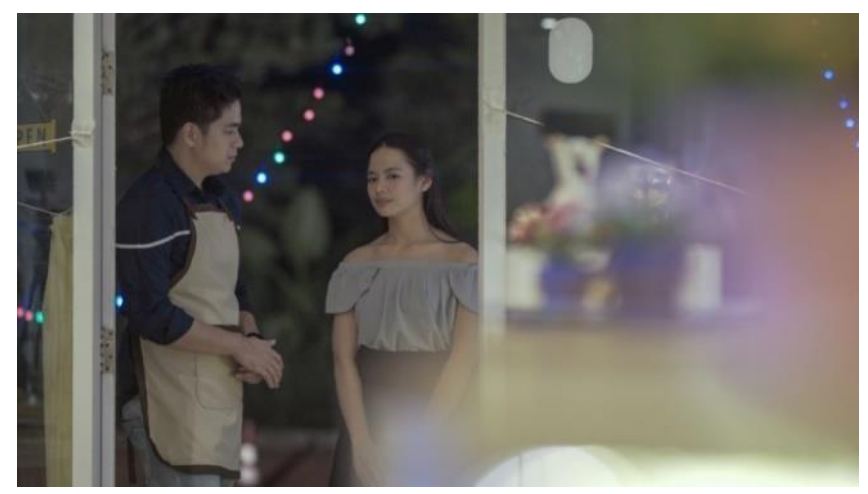

Gambar 1. Foto adegan ngabuburit series

Adegan Pengambilan visual dengan mengarah pada konsep pengambilan gambar, Di film Ngabuburit series memerlukan sebuah konsep visual menurut Oktania Imaniar selaku sutradara ngabuburit series adalah :

Konsep yang saya buat adalah realis, merujuk pada keseharian yang ada dan tidak dibuat-buat seperti setting café dengan pemilik dan karyawan, lalu pengunjung yang datang serta kegiatan seharihari. Selain peran, tugas dan fungsi Director of photograpy dalam sebuah pembuatan film ngabuburit series memperlukan sebuah konsep visual. Menurut Oktania Imaniar selaku sutradara. Berdasarkan beberapa kesimpulan tentang konsep visual wawancara di atas, maka peneliti menyimpulkan bahwa peran Director of Photography memang penting dalam proses produksi sebuah film, karena Director of photograpy yang menata segala aspek sinematography serta menentukan segala yang diperlukan dalam 
produksi ngabuburit series. Selain itu seorang Director of Photography bisa memberikan ide-ide yang baik untuk menentukan visual yang bagus, karena Director of Photography benar-benar berperan penting di produksi film ngabuburit series, dan selalu memberikan yang terbaik dan bekerja secara profesionalitas.

Dalam hal ini Peran Director of Photography dalam menginterpretasikan visual di film Ngabuburit Series, karena dalam pembuatan film yang realis, merujuk pada keseharian yang tidak dibuat-buat serta menata segala aspek sinematography seperti mulai dari lampu yang untuk menyesuaikan set dan lokasinya dan hanya beberapa tambahan fill in dari lampu yang mengarah pada objek tersebut tugasnya yang hampir keseluruhan ditangani oleh Director of Photography dari pencahayaan sampai pergerakan kamera.

Berdasarkan penelitian wawancara diatas, diperoleh bahwa peran seorang Director of photograpy sangat penting dalam sebuah proses produksi serta merupakan orang yang bertanggung jawab dalam segala aspek sinematography dan visual yang realis dari set sampai pencahayaannya sesuai arahan sutradara Seperti yang dijelaskan dalam buku Blain Brown (2013: 65) bahwa Director of Photograpy bertanggung jawab untuk memberikan apa yang sutradara inginkan. Setiap sutradara memiliki cara kerja yang berbeda- beda, ada yang sangat detil tentang "look"yang ia inginkan dan tentu saja framing, sedangkan ada yang focus terhadap actor dan pengadeganan dan menyerahkan kepada Director of photograpy untuk memutuskan framing, pergerakan kamera, pencahayaan dan sebagainya.

Sutradara sebagai pemimpin produksi mampu bekerja disegala model yang diharapkan. Director of Photograpy yang professional memiliki fleksibelitas untuk bekerja Bersama sutradara bagaimanapun sikapnya. Ini penting untuk didiskusikan sebelum proses shooting dimulai, dan jika Director of Photograpy tidak nyaman dengan cara sutradara bekerja, maka bisa ditanggulangi secepatnya. Peran Director Of Photograpy sangat besar untuk menyampaikan tampilan visual yang sutradara inginkan dan memastikan footage sesuai dengan keinginan sutradara dan editor.

Dalam penafsiran bahwa Peran Director of Photography dalam menginterpretasikan visual di film Ngabuburit Series, hasilnya film yang realis serta menata segala aspek sinematography seperti mulai dari lampu yang untuk menyesuaikan set dan lokasinya dan hanya beberapa tambahan fill in dari lampu yang mengarah pada objek tersebut tugasnya yang hampir keseluruhan ditangani oleh Director of Photography dari pencahayaan sampai pergerakan kamera. Dan menganalisa skenario dan sekaligus membahasnya bersama sutradara agar dapat mencapai tujuan bersama dalam penafsiran serta mewujudkan gagasan penulis dalam bentuk nyata dengan menciptakan konsep yang telah disepakati bersama untuk mencapai isi dalam ceritan tersebut.

\section{Kesimpulan}

Berdasarkan Visual Pada Web Series Di Youtobe (Studi Deskriptif Kualitatif Web Series Ngabuburit 2018), maka penulis menyimpulkan bahwa;

Dari hasil penelitian dan pembahasan dalam hasil penelitian yang telah peneliti uraikan diatas, maka dapat disimpulkan bahwa peran Director of photograpy dalam film ngabuburit series sangat penting Menentukan material kamera, menentukan shot, mengatur pencahayaan dan bertanggung jawab atas sinematografi di film ngabuburit series, selain itu director of photograpy harus bisa bekerja sama dengan crew lain dan menjadi ujung tombak sebuah proses produksi pembuatan film. Peran Director Of Photography dalam menginterpretasikan visual di film Ngabuburit Series, karena dalam pembuatan film yang realis, merujuk pada keseharian yang tidak dibuat-buat serta menata segala aspek sinematography seperti mulai dari lampu yang untuk menyesuaikan set dan lokasinya dan hanya beberapa tambahan fill in dari lampu yang mengarah pada objek tersebut tugasnya yang hampir keseluruhan ditangani oleh Director Of Photography dari pencahayaan sampai pergerakan kamera dan sebagai menganalisa skenario dan sekaligus membahasnya bersama sutradara agar dapat mencapai tujuan bersama dalam penafsiran.

Serta mewujudkan gagasan penulis dalam bentuk nyata dengan menciptakan konsep yang telah disepakati bersama untuk mencapai isi dalam ceritan tersebut. 


\section{JIKOM \\ Jurnal IImiah Komunikasi}

Volume 12, No.02, Juli. 2020

\section{References}

1. Ardianto Elvianto. Komunikasi Massa Edisi Revisi Kelima Simbiosa. Bandung : Rekatama Media ; 2014.

2. Ashfahani, Shulhuly. "Implementasi Keterbukaan dan Dukungan dalam Komunikasi Antarpribadi (Studi Komunikasi Pimpinan dan Karyawan di Sekolah Tinggi Ilmu Kesehatan Indonesia Maju)." Jurnal Ilmiah Komunikasi (JIKOM) STIKOM IMA 11.01 (2019): 187-195.

3. Fatimah. Digital Literacy and Its Relationship to Early Childhood Behavior in PAUD. Kanal [Internet]. 2020Sep.1 [cited 2020Oct.9];9(1):28- Available from: https://journal.umsida.ac.id/index.php/kanal/arti cle/view/663

4. Fatimah, Fatimah. "Komunikasi Persuasif Agen Asuransi Dalam Merekrut Calon Agen (Studi Kasus Tentang Perekrutan Calon Agen Dalam Meningkatkan Penjualan Polis di Asuransi PT. AXA)."Jurnalllmiah Komunikasi (JIKOM) STIKOM IMA10.02 (2018): 110-116

5. Pratiwi Fitri Dian. Strategi Kreatif Web Series Jalan-jalan Men Dalam Mengemas Konten Budaya Indonesia. Fakultas Ilmu Sosial Dan Ilmu Politik Universitas Sultan Ageng Tirtayasa; 2016.

6. Pratista Himawan. Memahami Film. Yogyakarta : Homeran Pustaka ; 2013.

7. Sobur Alex. Semiotika Komunikasi, Remaja Rosdakarya ; 2013.

8. http://duniasinematografi.blogspot.co.id

9. Blain Brow. Cinematograpy Theory And Practice Focal Press ; 2012.

10. Heru Efendy. Mari Membuat Film: Panduan Menujadi Produser. Jakarta : PT Erlangga ; 2013.

11. Iqbal Alfajri. Analisa Web Series Dalam Format Film Pendek (Studi Kasus Web Series "Malam Minggu Miko Episode Nissa). Institute Teknologi Bandung ; 2016.

12. Bordwell David. Film Art. An Introduction The Mc Graw-hill : Companies ; 2016.

13. Teguh Triantoro. Film Sebgai Media Belajar. Yogyakarta : Graha Ilmu ; 2013.

14. Bambang Semedhi. Sinematograpy- videografi:suatu pengantar. Bogor : Ghalia Indonesia ; 2011.

15. Muhammad Nur Sidiq. Materi workshop film indie. Yogyakarta : JCM UIN Sunan kalijaga ; 2014.

16. Sutirman Eka Ardgana. Modul matakuliah sinematograpy Yogyakarta : Fakultas Dakwah dan konunikasi dan komunikasi ; 2013.

17. Teguh triantoro. Film sebagai media belajar. Yogyakarta : Graha Ilmu ; 2013.

18. Fachurddin Andi. Dasar-dasar produksi televisi produksi berita feature, laporan invetigasi dokumenter dan Teknik editing. Jakarta : kencana ; 2012.

19. Setyadji, Veronika, and Phil Hermin Indah Wahyuni. Pengemasan Budaya Lokal Dalam Program Televisi Lokal (Studi Kasus Program Budaya â Adiluhungâ Pada Stasiun Televisi Lokal Yogyakarta â Jogya TVâ ). Diss. [Yogyakarta]: Universitas Gadjah Mada, 2013. 